\title{
PENGARUH SISTEM PENGENDALIAN INTERNAL DAN KEKUATAN KOERSIF TERHADAP KUALITAS LAPORAN KEUANGAN PEMERINTAH DAERAH
}

(Studi Pada Pemerintah Daerah Kabupaten/ Kota di wilayah I Bogor

Provinsi Jawa Barat)

\author{
Desiana Anugrah Budiawan \\ (Program Studi Akuntansi FPEB Universitas Pendidikan Indonesia) \\ Budi S. Purnomo \\ (Program Studi Akuntansi FPEB Universitas Pendidikan Indonesia)
}

\begin{abstract}
This research aims to empirically examine the effect of the internal control system and the coercive force of the quality of local government financial reports. The method used is descriptive method of verification. While the technique of data analysis using correlation coefficient analysis and coefficient of determination. Quantitative data is secondary and primary data. Secondary data in the form of examination reports on the financial statements of local government district / city in the first Bogor region of West Java province in 2012 were obtained from Badan Pemeriksa Keuangan (BPK). Sementara data primer dikumpulkan dari kepala seksi akuntansi pada pemerintah daerah kabupaten/ kota di wilayah I Bogor provinsi Jawa Barat. The results showed that the internal control system is not a positive influence on the quality of financial reports of local governments while the coercive power of positive influence on the quality of local government financial reports.
\end{abstract}

Keyword : internal control system, coercive power, financial report, quality of local government financial reports

\section{Pendahuluan}

Penyusunan laporan keuangan diperlukan guna memberikan informasi yang relevan mengenai posisi keuangan suatu entitas pada suatu periode akuntansi, sehingga laporan keuangan menjadi suatu alat yang sangat berguna untuk membantu top management dalam proses pengambilan keputusan. Di sektor pemerintahan, penyusunan laporan keuangan merupakan suatu kewajiban yang harus dilakukan pemerintah untuk mempertanggungjawabkan aktivitas keuangannya kepada publik/ masyarakat, sehingga kandungan informasi dalam laporan keuangan pemerintah harus benar-benar berkualitas. Kriteria dan unsurunsur pembentuk kualitas informasi laporan keuangan disebutkan dalam Kerangka Konseptual Akuntansi Pemerintahan (PP No. 71 tahun 2010) terdiri dari: (a) relevan, (b) andal, (c) dapat dibandingkan dan (d) dapat dipahami.

Laporan keuangan pemerintah harus memenuhi keempat karakteristik tersebut untuk mencapai tujuannya, karena keempat karakteristik itu merupakan prasyarat normatif yang diperlukan agar laporan keuangan pemerintah dapat memenuhi kualitas yang dikehendaki. Informasi yang terkandung di dalamlaporan keuangan yang dihasilkan oleh pemerintah daerah harus sesuai dengan kriteria nilai informasi yang disyaratkan oleh peraturan perundang-undangan. Apabila 
tidak sesuai dengan perundang-undangan, maka akan mengakibatkan kerugian daerah, potensi kekurangan daerah, kekurangan penerimaan, kelemahan administrasi, ketidakhematan, ketidakefisienan, dan ketidakfektifan. (Sukmaningrum, 2012)

Indonesia telah menerapkan otonomi daerah sebagaimana yang telah diamanatkan Undang-UndangNomor 32 Tahun 2004 tentang pemerintah daerah. UUini memberikan kewenangan daerah otonom untuk mengatur dan mengurus kepentingan masyarakat setempat menurut prakarsa sendiri berdasar aspirasi masyarakat sesuai dengan peraturan perundang-undanganan. Otonomi daerah yang luas dimaksudkan agar pemerintah daerah dapat meningkatkan efisiensi, efektifitas, dan akuntabilitas pemerintah daerah yang pada akhirnya diharapkan mampu mencapai good government governance (Muhamad Shodiqun dalam Wahyu Setiawan 2012).

Dengan adanya otonomi daerah maka terjadi perubahan dalam pengelolaan keuangan dibuktikan dengan lahirnya tiga paket undang-undang di bidang keuangan negara yaitu: UU Nomor 17 Tahun 2003 tentang Keuangan Negara; UU Nomor 1 Tahun 2004 tentang Perbendaharaan Negara; dan UU Nomor 15 tahun 2004 tentang Pemeriksaan atas Pengelolaan dan Pertanggungjawaban Keuangan Negara. Ketiga paket undang-undang ini mengatur pengelolaan keuangan negara secara lebih demokratis dan mengatur adanya sanksi bagi para pengelola keuangan negara. Hal ini menimbulkan konsekuensi bagi pemerintah daerah, yakni diberikan kewenangan untuk mengelola keuangan daerah masing-masing sehingga muncul adanya tuntutan transparansi dan akuntabilitas. Oleh karena itu, laporan keuangan pemerintah daerah akan diaudit oleh BPK RI sebagai auditor eksternal pemerintah daerah di Indonesia (Septiana Irma dkk, 2013).

Fenomena mengenai pelaporan keuangan pemerintahan daerah di Indonesia merupakan hal yang menarik untuk dikaji lebih lanjut, karena fakta di lapangan menunjukkan masih sering terdapat penyimpangan-penyimpangan yang ditemukan oleh BPK. BPK memberikan opini wajar tanpa pengecualian (WTP) atas 113 Laporan Keuangan Pemerintah Daerah (LKPD), opini wajar dengan pengecualian (WDP) atas 267 LKPD, opini tidak wajar (TW) atas 4 LKPD, dan opini tidak memberikan pendapat (TMP) atas 31 LKPD Tahun 2012. Dalam Ikhtisar Hasil Pemeriksaan Semester I (IHPS I) Tahun 2013 dilaporkan bahwa BPK menemukan 4.412 kasus kelemahan Sistem Pengendalian Internal (SPI) yang terdiri atas 1.586 kasus kelemahan sistem pengendalian akuntansi dan pelaporan, 1.935 kasus kelemahan sistem pengendalian pelaksanaan anggaran pendapatan dan belanja, 891 kasus kelemahan struktur pengendalian internal. Kasus-kasus kelemahan SPI tersebut diantaranya: (1) Kasus kelemahan sistem pengendalian akuntansi dan pelaporan di Provinsi Banten, laporan bulanan persediaan pada Dinas Kesehatan tidak dibuat dan nilai persediaan dari hasil stock opname tidak dapat diyakini, sehingga saldo persediaan pada Dinas Kesehatan per 31 Desember 2013 tidak dapat diyakini kewajarannya; (2)Kasus kelemahan sistem pengendalian pelaksanaan anggaran pendapatan dan belanja di Kabupaten Kuningan, Provinsi Jawa Barat, pemerintah Kabupaten Kuningan menunggak subsidi dan iuran asuransi kesehatan sejak Tahun 2004 kepada PT Askes (Persero) senilai Rp42,07 miliar mengakibatkan saldo utang semakin besar dan akan membebani APBD TA selanjutnya; (3) Kasus kelemahan struktur pengendalian 
internal di Kabupaten Bangkalan, Provinsi Jawa Timur, terdapat pembukaan 19 rekening untuk penerimaan dana kapitasi, dana askes rawat jalan, dan rawat inap atas nama pribadi dan tanpa melalui penetapan keputusan bupati mengakibatkan munculnya risiko atau peluang penyalahgunaan keuangan daerah.

Kasus-kasus kelemahan SPI tersebut pada umumnya terjadi karena para pejabat/ pelaksana yang bertanggung jawab tidak/ belum melakukan pencatatan secara akurat dan tidak menaati ketentuan dan prosedur yang ada, belum adanya kebijkan dan perlakuan akuntansi yang jelas, kurang cermat dalam melakukan perencanaan, belum melakukan koordinasi dengan pihak terkait, penetapan/ pelaksanaan kebijakan yang tidak tepat, belum menetapkan prosedur kegiatan, serta lemah dalam pengawasan dan pengendalian.

Selain kasus-kasus kelemahan SPI, BPK juga mengungkapkan ketidakpatuhan pemerintah daerah yang menyebabkan kerugian negara diantaranya ditemukannya 149 kasus belanja perjalanan dinas fiktif senilai Rp56.808,43 juta, juga sebanyak 89 kasus belanja atau pengadaan fiktif lainnya senilai Rp23.902,75 juta. Hal tersebut mungkin terjadi karena pemerintah daerah berusaha untuk memperoleh atau memperbaiki legitimasi, sehingga hanya menekankan aspek-aspek positif agar terlihat baik oleh pihak-pihak di luar organisasi. Kasus yang paling berat yang bisa saja dilakukan pemerintah untuk memperbaiki legitimasi adalah terjadinya creative accounting seperti manipulasi laporan keuangan. Dikutip dari beritasore.com bahwa disinyalir adanya manipulasi Laporan Keuangan Pemerintah Kota Binjai per 31 Desember 2008 tentang alat berat sebagai aset. Diduga keras 18 unit alat berat Pemerintah Kota Binjai digelapkan.

Selain itu ada juga kasus dugaan manipulasi laporan keuangan yang diduga dilakukan oleh Pemda Manggarai Timur Kupang, seperti yang dikutip dari tribunnews, fraksi PDIP DPRD Matim melaporkan kasus dugaan manipulasi APBD oleh Pemerintah Matim kepada Polres Manggarai. Fraksi mempersoalkan perselisihan angka yang termuat dalam buku APBD dan APBD perubahan tahun 2012 senilai Rp 509.145.986.764 atau (Rp509 M). Sementara dalam LKPj Bupati Matim tahun 2012 tercatat jumlah APBD Matim 2012 senilai Rp 531.417.415.971 (Rp $531 \mathrm{M}$ ).Berita lain dalam situs yang sama juga diungkapkan mengenai dugaan pemalsuan dokumen Anggaran Pendapatan dan Belanja Daerah (APBD) Perubahan 2012 Kabupaten Matim dengan masuknya dana siluman senilai Rp 21,2 miliar lebih.

Selain itu pemilihan subjek dalam penelitian ini didukung dengan fenomena pemberitaan kasus korupsi yang diduga dilakukan oleh salah satu kepala daerah di wilayah I Bogor Provinsi Jawa Barat ini yaitu daerah Kabupaten Bogor. Dikutip dari nasional.kompas.com: Bupati Bogor muncul dalam kasus dugaan suap kepengurusan izin lokasi taman pemakaman bukan umum (TPBU) di Desa Antajaya, Kecamatan Tanjung Sari, Bogor, Jawa Barat beserta enam orang lainnya. Munculnya pemberitaan ini membuat peneliti tertarik untuk mengetahui bagaimana kualitas laporan keuangan di daerah tersebut ketika kepala pemerintahannya tersandung kasus korupsi.

Namun disamping hal-hal negatif tersebut BPK juga menilai bahwa pemerintah masih mempunyai ruang yang cukup besar untuk meningkatkan kualitas penyajian laporan keuangannya. Hal tersebut dilihat dari jumlah LKPD yang memperoleh opini WTP meningkat dari 67 menjadi 113. Perbaikan opini 
tersebut antara lain karena entitas telah menindaklanjuti rekomendasi BPK. Perkembangan opini LKPD Tahun 2008 s.d. Tahun 2012 dapat dilihat dalam Tabel 1.1

Tabel 1.1

Perkembangan Opini LKPD Tahun 2008 s.d. 2012

\begin{tabular}{|c|c|c|c|c|c|c|c|c|c|}
\hline \multirow[b]{2}{*}{ Tahun LK } & \multicolumn{8}{|l|}{ Opini } & \multirow{2}{*}{$\begin{array}{l}\text { Jumlah } \\
\text { LKPD }\end{array}$} \\
\hline & WTP & $\%$ & $\begin{array}{l}\text { WD } \\
P\end{array}$ & $\%$ & TW & $\%$ & TMP & $\%$ & \\
\hline 2008 & 13 & $3 \%$ & 323 & $67 \%$ & 31 & $6 \%$ & 118 & $24 \%$ & 485 \\
\hline 2009 & 15 & $3 \%$ & 330 & $65 \%$ & 48 & $10 \%$ & 111 & $22 \%$ & 504 \\
\hline 2010 & 34 & $7 \%$ & 341 & $65 \%$ & 26 & $5 \%$ & 121 & $23 \%$ & 522 \\
\hline 2011 & 67 & $13 \%$ & 349 & $67 \%$ & 8 & $1 \%$ & 100 & $19 \%$ & 524 \\
\hline 2012 & 113 & $27 \%$ & 267 & $64 \%$ & 4 & $1 \%$ & 31 & $8 \%$ & 415 \\
\hline
\end{tabular}

(sumber: www.bpk.go.id-IHPS I Tahun 2013)

Sampai dengan Semester I Tahun 2013, opini baru diberikan kepada 415

LKPD Tahun 2012, karena belum seluruh pemerintah daerah dapat menyelesaikan penyusunan laporan keuangan dan/atau terlambat menyerahkan laporan keuangan kepada BPK.Berdasarkan Tabel 1.1 terlihat bahwa dari Tahun 2008 sampai dengan Tahun 2012 secara bertahap jumlah pemerintah daerah yang memperoleh opini WTP semakin meningkat dari 13 entitas di Tahun 2008 menjadi 113 entitas di Tahun 2012. Kualitas penyajian LKPD terus menunjukkan peningkatan dari tahun ke tahun. Hasilnya antara lain terlihat dari peningkatan persentase LKPD yang memperoleh opini WTP yaitu dari 3\% pada Tahun 2008 menjadi $27 \%$ pada Tahun 2012 atau meningkat sebanyak 24\%. Di samping peningkatan persentase opini WTP, perbaikan kualitas penyajian laporan keuangan juga terlihat dari penurunan jumlah persentase opini WDP, TW dan TMP pada periode tahun yang sama. Kecenderungan peningkatan persentase opini WTP dan penurunan persentase opini selain WTP ini menggambarkan peningkatan keandalan data dan informasi yang disajikan di LKPD dan upaya optimal yang dilakukan oleh pemerintah daerah dalam memperbaiki penyajian laporan keuangan termasuk melaksanakan rekomendasi BPK.

Berdasarkan fenomena-fenomena tersebut, dapat disimpulkan bahwa laporan keuangan yang dihasilkan oleh pemerintah masih belum memenuhi kriteria nilai informasi yang disyaratkan. Sehingga memunculkan pertanyaan apakah Pemerintah Daerah Kabupaten/ Kota di wilayah I Provinsi Jawa Barat dapat menghasilkan LKPD yang berkualitas dan apakah sistem pengendalian internal juga kekuatan koersif mempengaruhi kualitas LKPD. Terkait dengan konteks inilah, muncul pertanyaan seberapa baik sistem pengendalian internal dan seberapa berpengaruh kekuatan koersif yang dirasakan oleh akuntan dan apakah sistem pengendalian internal dan kekuatan koersif yang dirasakan akuntan tersebut dapat mempengaruhi kualitas LKPD yang dihasilkan.

Mengingat bahwa karakterisktik kualitatif merupakan unsur penting dalam Laporan Keuangan Pemerintah sebagai dasar pengambilan keputusan, maka peneliti tertarik untuk menginterpretasikan dan menjelaskan bukti empiris tersebut 279 | Jurnal Riset Akuntansi dan Keuangan Vol.2 | No.1 | 2014 
dari perspektif teori institusional (institutional theory). Teori institusional digunakan untuk mengetahui sejauh mana laporan keuangan yang berkualitas dapat diciptakan didorong oleh adanya fenomena isomorfisme (koersif, mimetik, dan normatif). Pada penelitian kali ini peneliti akan berusaha menekankan pada isomorfisme koersif yaitu tekanan eksternal yang berhubungan dengan lingkungan di sekitar organisasi. Pada sektor pemerintahan banyak sekali peraturan perundang-undangan yang mengatur proses pelaporan keuangan secara teknis. Adanya peraturan ditujukan untuk mengatur praktik yang ada agar menjadi lebih baik. Di sisi lain, kekuatan koersif dari suatu peraturan dapat menyebabkan adanya kecenderungan organisasi untuk memperoleh atau memperbaiki legitimasi (legitimate coercion), sehingga hanya menekankan aspek-aspek positif agar organisasi terlihat baik oleh pihak-pihak di luar organisasi (Ridha, 2012).

Kualitas laporan keuangan pemerintah biasanya dinilai dari opini yang diberikan oleh BPK selaku auditor eksternal. Opini merupakan pernyataan profesional pemeriksa mengenai kewajaran informasi keuangan yang disajikan dalam laporan keuangan yang didasarkan pada kriteria: (a) kesesuaian dengan standar akuntansi pemerintahan, (b) kecukupan pengungkapan (adequate disclosure), (c) kepatuhan terhadap peraturan perundang-undangan, dan (d) efektifitas sistem pengendalian internal (SPI). Dalam penelitian kali ini peneliti hanya menekankan pada faktor sistem pengendalian internal (SPI), mengingat keterbatasan data yang dapat peneliti kumpulkan hanya bersumber pada Indeks Hasil Pemeriksaan Semester (IHPS) I tahun 2013 Badan Pemeriksa Keuangan Republik Indonesia. Selain itu juga faktor sistem pengendalian internal dirasa sangat berpengaruh terhadap kualitas laporan keuangan yang disusun. Buktinya hasil temuan BPK menyatakan bahwa pemberian opini WDP pada sebagian besar LKPD tahun 2012 yang didasarkan pada adanya temuan berulang pada sistem pengendalian internalnya yaitu terdapat kelemahan dalam pencatatan asset tetap.

Berdasarkan uraian di atas, maka permasalahan yang dapat diidentifikasi penulis adalah sebagai berikut : (1) Bagaimana pengaruhsistem pengendalian internal terhadap kualitas laporan keuangan pemerintah daerah? (2) Bagaimana pengaruhkekuatan koersif terhadap kualitas laporan keuangan pemerintah daerah?

\section{Kajian Pustaka}

Pemerintah harus mampu menyajikan laporan keuangan dengan informasi yang berkualitas agar dapat dimengerti oleh para penggunanya termasuk masyarakat karena masyarakat memiliki hak dasar untuk tahu (basic right to know) dan memperoleh informasi mengenai apa yang sedang dilakukan pemerintah, dan mengapa suatu kebijakan atau program dilakukan (Stiglitz, 1999) serta bagaimana organisasi menjalankan operasionalnya (Silver, 2005).Untuk menghasilkan laporan keuangan yang berkualitas, harus ada pengendalian internal yang efektif dari pemerintah itu sendiri, dan pemerintah juga harus mampu mengendalikan tekanan eksternal yang dapat mengganggu stabilitas penyusunan laporan keuangan.

Menurut Sofyan Syafri (2007) kualitas laporan keuangan adalah ciri khas yang membuat informasi dalam laporan keuangan bermanfaat bagi para penggunanya.Namun demikian, praktiknya sering jauh dari yang diharapkan. Opini LKPD yang mayoritas masih WDP mencerminkan bahwa kualitas laporan keuangan pemerintah masih belum maksimal. 
$\mathrm{Xu}$, et al. (2003) menjelaskan bahwa interaksi antara orang dan sistemserta implementasi sistem merupakan faktor penting yang mempengaruhi kualitasdari sebuah informasi. Namun sistem yang sudah berjalan harus dikontrol agartetap dapat berjalan baik.Sistem pengendalian internal menurut Gondodiyoto (2007) adalah suatu mekanisme yang didesain untuk menjaga (preventif), mendeteksi (detektif), dan memberikan mekanisme pembetulan (korektif) terhadap potensi/ kemungkinan terjadinya kesalahan (kekeliruan, kelalaian, error) maupun penyalahgunaan (kecurangan, fraud).

Pengendalian internal merupakan salah satu fondasi terkuat good governance. Sistem pengendalian intern meliputi berbagai alat manajemen yang bertujuan untuk mencapai berbagai tujuan yang luas. Tujuan tersebut yaitu menjamin kepatuhan terhadap hukum dan peraturan, menjamin keandalan laporan keuangan dan data keuangan, memfasilitasi efisiensi dan efektivitas operasi pemerintah, dan menjamin pengamanan aset negara. Menurut Mardiasmo (2004) dalam Aristanti (2011) sistem akuntansi yang lemah menyebabkan pengendalian intern lemah dan pada akhirnya laporan keuangan yang dihasilkan juga kurang handal dan kurang relevan untuk pembuatan keputusan.

Masih ditemukannya penyimpangan dan kebocoran di dalam laporan keuangan oleh BPK, menunjukkan bahwa Laporan Keuangan Pemerintah belum memenuhi karakteristik/nilai informasi yang disyaratkan. Hasil audit yang dilakukan oleh BPK, BPK memberikan opini "wajar dengan pengecualian/ qualified opinion" diantaranya disebabkan oleh kelemahan sistem pengendalian intern yang dimiliki oleh pemerintah. (Badan Pemeriksa Keuangan, 2011).

Pengendalian intern merupakan bagian dari manajemen resiko yang harus dilaksanakan oleh setiap lembaga atau organisasi untuk mencapai tujuan lembaga atau organisasi. Penerapan pengendalian intern yang memadai akan memberikan keyakinan yang memadai atas kualitas atau keandalan laporan keuangan, serta akan meningkatkan kepercayaan stakeholders. (Sukmaningrum, 2012).

Disamping pengendalian internal yang memadai organisasi/ lembaga juga harus mampu mengendalikan segala bentuk tekanan yang menghampirinya. Salah satunya adalah tekanan eksternal berupa peraturan dan tata kelola yang diatur secara tertulis. Ridha (2012) mengatakan adanya peraturan ditujukan untuk mengatur praktik yang ada agar menjadi lebih baik. Namun di sisi lain, kekuatan koersif dari suatu peraturan dapat menyebabkan adanya kecenderungan organisasi untuk memperoleh atau memperbaiki legitimasi (legitimate coercion) (scott, 1987), sehingga hanya menekankan aspek-aspek positif (Hess, 2007) agar organisasi terlihat baik oleh pihak-pihak di luar organisasi.Isomorfisme koersif selalu terkait dengan segala hal yang terhubung dengan lingkungan di sekitar organisasi.

Perubahan organisasi yang didasari kekuatan koersif akan menyebabkan organisasi lebih mempertimbangkan pengaruh politik dari pada teknis (Ashworth, 2009). Perubahan organisasi yang lebih dipengaruhi politik akan mengakibatkan praktik-praktik yang terjadi dalam organisasi, khususnya terkait penyusunan laporan keuangan akan hanya bersifat formalitas yang ditujukan untuk memperoleh legitimasi.Frumkin dan Galaskiewicz dalam Ridha (2012) menyatakan bahwa tekanan eksternal dapat mempengaruhi tingkat kemampuan pemerintahan menjadi lebih rendah, terutama yang terkait dengan penerepan suatu kebijakan maupun prosedur. Hal ini dikarenakan aspek hukum dan politik 
memiliki dua karakteristik yang khusus dan kurang lazim terdapat pada aspek lain. Pertama, aspek ini mempengaruhi dan mengikat seluruh anggota masyarakat. Dalam hal ini tidak ada seorangpun anggota masyarakat yang bebas memilih hukum dan politik di dalam masyarakatnya. Karakteristik yang kedua adalah bahwa aspek politik dan hukum menguasai kekuatan fisik dan kekuatan hukum memonopoli kekuatan untuk memaksakan kehendaknya terhadap setiap organisasi walaupun kekuatan hukum dan politik terikat oleh kehendak dan kekuatan masyarakat secara umum (Yayat, 2002).

\section{Metode Penelitian}

Penelitian ini menggunakan metode deskriptif verifikatif dimana penulis akan mencoba untuk menjawab pengaruh antar variabel yang ada. Dalam penelitian ini, penulis berusaha mengumpulkan data primer dan data sekunder. Data sekunder berupa ikhtisarhasil pemeriksaan atas laporan keuangan pemerintah daerah kabupaten/kota tahun 2012 di seluruhIndonesia yang diperoleh dari Badan Pemeriksa Keuangan (BPK RI). Sementara data primer diperoleh melalui penyebaran kuesioner. Kuesioner dalam penelitian ini disusun menggunakan Skala Likert. Populasi yang digunakan dalam penelitian ini adalah Pemerintah Daerah Kabupaten/ Kota di wilayah I Bogor Provinsi Jawa Barat, dengan responden kepala seksi akuntansi. Sebelum dilakukan analisis lebih lanjut, instrumen penelitian diuji terlebih dahulu dengan menggunakan uji validitas dan reliabilitas. Adapun alat analisis yang digunakan selanjutnya adalah analisis koefisien korelasi Rank Spearman dan analisis koefisien determinasi.

Dalam penelitian ini metode yang digunakan dalam uji validitas adalah korelasi Rank Spearman. Pengujian validitas dilakukan dengan menghitung korelasi antara masing-masing pertanyaan dengan skor total. Analisis ini digunakan untuk mengetahui pernyataan mana yang valid dengan mengacu pada tingkat signifikan sebesar 0,811 ( $\mathrm{r}_{\mathrm{s}} \mathrm{kritis}$ ) pada $\mathrm{n}=6$. Jika $\mathrm{r}$ korelasi $<0,811$ maka pernyataan tidak valid, sedangkan jika $\mathbf{r}_{\mathrm{s}}$ korelasi $>0,811$ maka pernyataan valid. Pengujian validitas untuk variabel Kekuatan Koersif yang diolah berdasarkan hasil penyebaran kuesioner yang dijabarkan ke dalam 10 pernyataan dengan 6 responden di pemerintah daerah wilayah I Bogor provinsi Jawa Barat. Berdasarkan Hasil Uji Validitas variabel Kekuatan Koersif, semua pernyataan dari variabel tersebut yang berjumlah 10 pernyataan dinyatakan valid dan akan digunakan untuk uji reliabilitas dan analisis selanjutnya.

Metode yang digunakan untuk uji reliabilitas dalam penelitian ini adalah metode koefisien Alpha Cronbach's.Suatuvariabel dikatakan reliabel jika harga r yang diperoleh paling tidak 0,60. Di pihak lain, untuk tes-tes standar yang atau distandarkan, harga indeks reliabilitas itu paling tidak harus mencapai 0,85 atau bahkan 0,90 (Burhan dkk, 2004).Hasil perhitungan uji reliabilitas pada variabel Kekuatan Koersif dengan menggunakan software SPSS 20.0 for windows dapat dilihat pada tabel 3.5:

Tabel 3.5

Hasil Uji Reliabilitas Variabel Kekuatan Koersif 


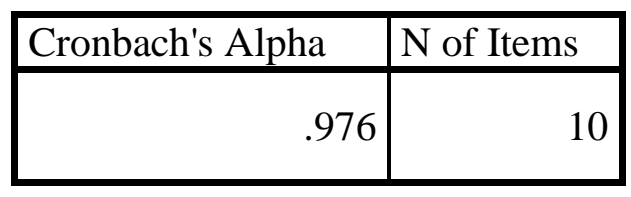

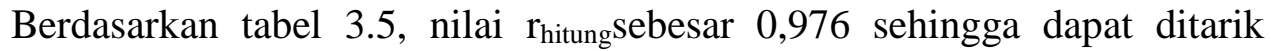
kesimpulan bahwa ke-10 pernyataan yang valid dalam kuesioner untuk variabel Kekuatan Koersif adalah reliabel.

Selanjutnya teknik analisis koefisien korelasi digunakan untuk melihat arah hubungan antara variabel $\mathrm{X}$ terhadap variabel $\mathrm{Y}$ digunakan alat hitung dengan menggunakan statistik hitung korelasi rank spearman, dengan rumus:

$$
\rho=1-\frac{6 \sum b_{i}^{2}}{n\left(n^{2}-1\right)}
$$

Keterangan:

(Sugiyono, 2010)

$\mathrm{b}_{\mathrm{i}}=$ Selisih rank Xi dengan rank $\mathrm{Yi}$

$\mathrm{n}=$ banyak data

Sementara menurut Supranto (2003), koefisien determinasi adalah bagian dari keragaman total variabel $Y$ (terikat) yang dapat diterangkan atau diperhitungkan oleh keragaman variabel $X$ (bebas), yaitu koefisien yang mengukur besarnya persentase kontribusi variasi X terhadap Y. Analisis ini digunakan untuk menilai seberapa besar variabel $\mathrm{X}$ dapat memberikan pengaruh terhadap variabel Y dengan rumus sebagai berikut:

Keterangan:

$$
K d=r_{s}^{2} \times 100 \%
$$

$\mathrm{Kd} \quad=$ Koefisien Determinasi

$\mathrm{r}_{\mathrm{s}} \quad=$ Koefisien Korelasi Rank Spearman

\section{Hasil dan Pembahasan}

Pada bagian ini hipotesis konseptual yang sebelumnya diajukan diuji melalui uji statistik. Hipotesis konseptual yang diajukan seperti yang telah dituangkan sebelumnya adalah adanya pengaruh dari variabel sistem pengendalian internaldan kekuatan koersif terhadap kualitas laporan keuangan pemerintah daerah. Analisis statistik yang digunakan adalah analisis koefisien korelasi untuk menyatakan arah hubungan variabel independen dan variabel dependennya, dan analisis koefisien determinasi untuk mengetahui besarnya kontribusi variabel independen terhadap variabel dependennya.

\section{Pengaruh Sistem Pengendalian Internal terhadap Kualitas Laporan Keuangan}

1. Hasil Analisis Koefisien Korelasi Rank Spearman

Berikut ini adalah tabel hasil perhitungan koefisien korelasi Rank Spearmanuntuk variabel Sistem Pengandalian Internal terhadap Kualitas Laporan Keuangan dengan pengolahan datanya menggunakan bantuan software statistik SPSS 20.0 for Windows yaitu sebagai berikut:

\section{Tabel 4.13}

\section{Hasil Analisis Koefisien Korelasi Rank Spearman Variabel}




\section{Sistem Pengendalian Internal} Correlations

\begin{tabular}{|c|c|c|c|c|}
\hline & & & Rank of $\mathrm{X} 1$ & Rank of $Y$ \\
\hline Spearman's rho & $\begin{array}{l}\text { Rank of } \mathrm{X} 1 \\
\text { Rank of } Y\end{array}$ & $\begin{array}{l}\text { Correlation Coefficient } \\
\text { Sig. (1-tailed) } \\
\mathrm{N} \\
\text { Correlation Coefficient } \\
\text { Sig. (1-tailed) } \\
\mathrm{N}\end{array}$ & $\begin{array}{l}1.000 \\
. \\
6 \\
-.200 \\
.352 \\
6\end{array}$ & $\begin{array}{l}-.200 \\
.352 \\
6 \\
1.000 \\
. \\
6\end{array}$ \\
\hline
\end{tabular}

Berdasarkan hasil perhitungan analisis koefisien korelasi Rank Spearman di atas, dapat diketahui bahwa nilai koefisien korelasi antara variabel Sistem Pengendalian Internal dan Kualitas Laporan Keuangan adalah sebesar -0,200. Hal tersebut menunjukkan bahwa sistem pengendalian internal tidak memiliki hubungan positif dengan kualitas laporan keuangan pemerintah daerah di wilayah I Bogor provinsi Jawa Barat. Nilai koefisien korelasi -0,200 termasuk dalam kategori rendah, artinya apabila rata-rata skor sistem pengendalian internal meningkat satu satuan, maka diprediksikan rata-rata skor kualitas laporan keuangan rendah. Nilai ini digunakan untuk menguji hipotesis statistik berikut ini:

$\mathrm{H}_{0}: \rho \leq 0, \quad$ Artinya sistem pengendalian internal tidak berhubunganpositif terhadap kualitas laporan keuangan

$\mathrm{H}_{\mathrm{a}}: \rho>0$, Artinya sistem pengendalian internal berhubunganpositif terhadap kualitas laporan keuangan

2. Hasil Analisis Koefisien Determinasi

Setelah mengetahui besar dan arah hubungan variabel Sistem Pengendalian Internal dan Kekuatan Koersif terhadap variabel Kualitas Laporan Keuangan, selanjutnya adalah menilai seberapa besar variabel Sistem Pengendalian Internal dapat memberikan pengaruh terhadap Variabel Kualitas Laporan Keuangan dengan menggunakan analisis koefisien determinasi sebagai berikut:

$$
\begin{gathered}
K d=r_{s}^{2} \times 100 \% \\
K d=(-0,200)^{2} \times 100 \%=4 \%
\end{gathered}
$$

Dimana: $\mathrm{Kd}=4 \%$ (nilai koefisien determinasi, besarnyapengaruh variabel Sistem Pengendalian Internal terhadap variabel Kualitas Laporan Keuangan) $\mathrm{r}_{\mathrm{s}}=-0,200$ (nilai koefisien korelasi dan arah hubungan variabel Kekuatan Koersif terhadap variabel Kualitas Laporan Keuangan)

Berdasarkan hasil pengujian diatas, dapat diketahui bahwa nilai koefisien korelasi untuk variabel bebas yaitu sistem pengendalian internal adalah sebesar 0,200 dan koefisien determinasi sebesar 4\%. Dilihat dari arah hubungannya yaitu negatif, maka dalam penelitian ini hipotesis penelitian ditolak. Artinya, sistem pengendalian internal tidak berpengaruh positif terhadap kualitas laporan keuangan pemerintah daerah di wilayah I Bogor provinsi Jawa Barat.

\section{Pengaruh Kekuatan Koersif terhadap Kualitas Laporan Keuangan}

1. Hasil Analisis Koefisien Korelasi Rank Spearman

Berikut ini adalah tabel hasil perhitungan koefisien korelasi Rank Spearmanuntuk variabel Kekuatan Koersif terhadap variabel Kualitas Laporan Keuangan dengan pengolahan datanya menggunakan bantuansoftware statistik SPSS 20.0 for Windows yaitu sebagai berikut:

\section{Tabel 4.14}




\section{Hasil Analisis Koefisien Korelasi Rank Spearman Variabel Kekuatan Koersif}

\begin{tabular}{|c|c|c|c|c|}
\hline \multicolumn{5}{|c|}{ Correlations } \\
\hline & & & Rank of $x$ & Rank of y \\
\hline \multirow{6}{*}{ Spearman's rho } & & Correlation Coefficient & 1.000 & .707 \\
\hline & Rank of $x$ & Sig. (1-tailed) & & .058 \\
\hline & & $\mathrm{N}$ & 6 & 6 \\
\hline & & Correlation Coefficient & .707 & 1.000 \\
\hline & Rank of $y$ & Sig. (1-tailed) & .058 & \\
\hline & & $\mathrm{N}$ & 6 & 6 \\
\hline
\end{tabular}

Berdasarkan hasil perhitungan analisis koefisien korelasi Rank Spearman di atas, dapat diketahui bahwa nilai koefisien korelasi antara variabel Kekuatan Koersif dan Kualitas Laporan Keuangan adalah sebesar 0,707. Hal tersebut menunjukkan bahwa kekuatan koersif memiliki hubungan positif dengan kualitas laporan keuangan pemerintah daerah di wilayah I Bogor provinsi Jawa Barat. Nilai koefisien korelasi0,707 termasuk dalam kategori kuat, artinya apabila ratarata skor kekuatan koersif meningkat satu satuan, maka diprediksikan rata-rata skor kualitas laporan keuangan tinggi. Nilai ini digunakan untuk menguji hipotesis statistik berikut ini:

$$
\begin{array}{ll}
\mathrm{H}_{0}: \rho \leq 0, & \begin{array}{l}
\text { Artinya kekuatan koersif tidak berhubunganpositif terhadap } \\
\text { kualitas laporan keuangan }
\end{array} \\
\mathrm{H}_{\mathrm{a}}: \rho>0, & \begin{array}{l}
\text { Artinya kekuatan koersifberhubunganpositif terhadap } \\
\text { kualitas laporan keuangan }
\end{array}
\end{array}
$$

\section{Hasil Analisi Koefisien Determinasi}

Selanjutnya berikut ini adalah hasil perhitungan koefisien determinasi untuk variabel Kekuatan Koersif terhadap variabel Kualitas Laporan Keuangan:

$$
\begin{gathered}
K d=r_{s}^{2} \times 100 \% \\
K d=(0,707)^{2} \times 100 \%=49,9 \%
\end{gathered}
$$

Dimana: $\mathrm{Kd}=49,9 \%$ (nilai koefisien determinasi, besarnyapengaruh variabel Kekuatan Koersif terhadap variabel Kualitas Laporan Keuangan)

$\mathrm{r}_{\mathrm{s}}=0,707$ (nilai koefisien korelasi dan arah hubungan variabel Kekuatan Koersif terhadap variabel Kualitas Laporan Keuangan)

Berdasarkan hasil pengujian diatas, dapat diketahui bahwa nilai koefisien korelasi untuk variabel bebas yaitu kekuatan koersif adalah sebesar 0,707 dan koefisien determinasi sebesar 49,9\%. Dilihat dari arah hubungannya yaitu positif, maka dalam penelitian ini hipotesis penelitian diterima. Artinya, kekuatan koersif berpengaruh positif terhadap kualitas laporan keuangan pemerintah daerah di wilayah I Bogor provinsi Jawa Barat.

\section{Simpulan}

Berdasarkan hasil penelitian mengenai pengaruh sistem pengendalian internal dan kekuatan koersif terhadap kualitas laporan keuangan pada Pemerintah Daerah Kabupaten/ Kota wilayah I Bogor Provinsi Jawa Baratdapat ditarik simpulan sebagai berikut: (1) Sistem pengendalian internal tidak berpengaruh positif terhadap kualitas laporan keuangan Pemerintah Daerah Kabupaten/ Kota wilayah I Bogor Provinsi Jawa Barat. Sistem pengendalian internal yang baik belum tentu akan meningkatkan kualitas laporan keuangan Pemerintah Daerah Kabupaten/ Kota di wilayah I Bogor Provinsi Jawa Barat. (2) Kekuatan koersif 285 | Jurnal Riset Akuntansi dan Keuangan Vol.2 | No.1 | 2014 
berpengaruh positif terhadap kualitas laporan keuangan Pemerintah Daerah Kabupaten/ Kota wilayah I Bogor Provinsi Jawa Barat. Jika kekuatan koersif meningkat maka kualitas laporan keuangan Pemerintah Daerah Kabupaten/ Kota di wilayah I Bogor Provinsi Jawa Barat juga akan meningkat.

\section{Saran}

Berdasarkan hasil penelitian yang telah diuraikan dan simpulan yang diperoleh, maka terdapat beberapa saran yang penulis sampaikan sehubungan dengan pengaruh sistem pengendalian internal dan kekuatan koersif terhadap kualitas laporan keuangan pemerintah daerah beserta hal lainnya yang terkait, yaitu: (1) Berdasarkan hasil penelitian bahwa sistem pengendalian internal tidak berpengaruh positif terhadap kualitas laporan keuangan pemerintah daerah wilayah I Bogor Jawa Barat. Hal tersebut menunjukkan bahwa kualitas laporan keuangan tidak hanya dinilai dari efektivitas pengendalian internalnya saja, sehingga aparatur pemerintah harus mampu memenuhi aspek-aspek lain untuk menghasilkan laporan keuangan yang dinilai berkualitas. Aspek-aspek tersebut diantaranya kesesuaian dengan standar akuntansi pemerintahan, kecukupan pengungkapan (adequate disclosure), dan kepatuhan terhadap peraturan perundang-undangan. (2) Kelemahan dari penelitian ini adalah adanya keterbatasan data yang penulis miliki dimana data sekunder yang digunakan tidak dapat mengukur seberapa fatal temuan kasus kelemahan sistem pengendalian internal masing-masing daerah, maka untuk peneliti selanjutnya yang tertarik untuk melakukan penelitian serupa dapat melakukan penelitian lanjutan dengan menggunakan data sekunder lain yang menunjukkan materialitas dari masingmasing temuan kelemahan SPI atau menggunakan data primer berupa kuesioner.

(3) Peneliti selanjutnya diharapkan dapat memperluas wilayah penelitian tidak hanya pada Pemerintah Daerah wilayah I Bogor saja. Selain itu dapat juga menambah variabel independen agar penelitian dapat menggambarkan faktorfaktor yang mempengaruhi Kualitas Laporan Keuangan seperti teknologi informasi dan kualitas sumber daya manusia.

\section{Daftar Pustaka}

........ (2010, 08 Oktober). Walikota Binjai Diminta Audit Kembali Laporan Keuangan 2008. Beritasore.com [Online]. Tersedia: http://beritasore.com/2010/10/08/walikota-binjai-diminta-audit-kembalilaporan-keuangan-2008/ [09 April 2014]

Arens, Alvin A., et al. (2006). Auditing and Assurance Services $12^{\text {th }}$ edition. New Jersey: Prentice-Hall Inc.

Aristanti Widyaningsih, dkk. (2011). Hubungan Efektifitas Sistem Akuntansi Keuangan Daerah Dan Pengendalian Intern Dengan Kualitas Akuntabilitas Keuangan: Kualitas Informasi Laporan Keuangan Sebagai Variabel Intervening, dalam SNA XIV. Aceh.

Badan Pemeriksa Keuangan Republik Indonesia. (2013). Ikhtisar Hasil Pemeriksaan Semester I Tahun 2013. Jakarta

Burhan Nurgiyantoro, dkk. (2004). Statistik Terapan. Yogyakarta: Gajah Mada University Press. 
Butar Butar, Daniel. (2011). Pengaruh Kompensasi Eksekutif Dan Manajemen LabaTerhadap Risiko Kebangkrutan Pada Perusahaan Manufaktur Yang TerdaftarDi Bursa Efek Indonesia. Skripsi. Universitas Sumatera Utara.

Cris Defera. (2013). Pengaruh Kelemahan Sistem Pengendalian Intern DanKetidakpatuhan Pada Ketentuan Perundang-UndanganTerhadap Penentuan Opini Laporan KeuanganPemerintah Daerah Di Indonesia Tahun 2008-2011.Skripsi. Yogyakarta: Universitas Atma Jaya.

Darya Setya Nugraha dan Apriyanti Susanti. (2010). "The Influence of Internal Control System to The Reliability of Local Government Financial Statement (Case Study at Pemerintah Provinsi Jawa Barat)". Jurnal Ekonomi, Keuangan, Perbankan, dan Akuntansi, Vol. 2 No. 2, 259-280

DiMaggio, Paul. J., and Walter, W. Powell. (1983). "The Iron Cage Revisited:Institutional Isomorphism and Collective Rationality In Organizational Fields".American Sociological Review. 48:147-60.

Donaldson, Thomas, Preston, Lee E. (1995). "The Stakeholder Theory of The Corporation: Concepts, Evidence, and Implications". Academy Management Review, Vol.20, No.1, 65-91.

Egy, Moa (2014, 19 Maret). Dugaan Pemalsuan Dokumen APBDP, Banggar Pemkab Matim Diperiksa Polisi. tribunnews.com [Online]. Tersedia: http://kupang.tribunnews.com/2014/03/19/dugaan-pemalsuan-dokumenapbdp-banggar-pemkab-matim-diperiksa-polisi [09 April 2014]

Harahap, Sofyan Syafri. (2007). Analisis Kritis atas Laporan Keuangan.Jakarta: PT RajaGrafindo Persada.

Harahap, Sofyan Syafri. (2007). Teori Akuntansi. Jakarta: PT Raja Grafindo Persada.

Harwanto. (2012, 29 Mei). Kualitas Laporan keuangan Pemerintah Pusat Masih Belum Maksimal. Merdeka.com [Online]. Tersedia: http://www.merdeka.com/uang/kualitas-laporan-keuangan-pemerintahpusat-masih-belum-maksimal.html [11 Desember 2013]

HasanIqbal. (2008). Analisis Data Penelitian Dengan Statistik. Jakarta: PT Bumi Aksara.

Husein Umar. (2008). Desain Penelitian Akuntansi Keprilakuan. Jakarta: Raja Grafindo Persada.

Icha Rastika. (2014, 8 Mei). Rachmat Yasin, Bupati Bogor yang "Akrab" di KPK...nasional.kompas.com [Online]. Tersedia: http://nasional.kompas.com/read/2014/05/08/1144136/Rachmat.Yasin.Bupa ti.Bogor.yang.Akrab.di.KPK. [27 Mei 2014]

Ikatan Akuntan Indonesia (IAI). (2007). Standar Akuntansi Keuangan (PSAK). Jakarta:Salemba Empat.

Indra Bastian. (2007). Audit Sektor Publik. Jakarta: Salemba Empat.

J. Supranto. (2003).Statistik Teori dan Aplikasi Edisi Lima. Jakarta: Erlangga.

M. Arsyadi Ridha. (2012). Pengaruh Tekanan Eksternal, Ketidakpastian Lingkungan, Dan Komitmen Managemen Terhadap Penerapan Transparansi Pelaporan Keuangan, dalam SNA XV. Banjarmasin.

Pemerintah Provinsi Jawa Barat. (2013). Sekilas Jawa Barat. [Online] Tersedia: jabarprov.go.id.

Rachel Ashworth, et al. (2009). "Escape from the Iron Cage? OrganizationalChange and Isomorphic Pressures in thePublic Sector". 
Journal of Public Administration Research and Theory. JPART 19:165187.

Republik Indonesia, Peraturan Pemerintah Nomor 60 Tahun 2008 tentang Sistem Pengendalian Intern Pemerintah.

Republik Indonesia, Peraturan Pemerintah Nomor 71 Tahun 2010 tentang Standar Akuntansi Pemerintahan.

Republik Indonesia, Undang-Undang No. 32 tahun 2004 tentang Pemerintah Daerah.

Rusdi Akbar, et al. (2012). "Performance measurementin Indonesia: the case of localgovernment”. Pacific Accounting Review. Vol. 24 No. 3, 262-291.

Sanyoto Gondodiyoto. (2007). Audit Sistem Informasi + Pendekatan CobIT . Jakarta: Mitra Wacana Media.

Scott, Richard. (2001). Institutionalism and Organization.London: Sage Publication, Thoasand OaKS.

Sentot Imam Wahjono. (2010). Perilaku Organisasi. Yogyakarta: Graha Ilmu.

Septiana Irma, dkk (2013). Penentu Jumlah Temuan BPK atasSistem Pengendalian Intern dan Kepatuhan(Internal Control Compliance Comments)Pemerintah Daerah di Indonesia, dalam SNA XVI. Manado.

Siagian, Fretty. (2011). Pengaruh Corporate Governance, Ukuran Perusahaan dan Struktur Kepemilikan Terhadap Manajemen Laba Pada Perusahaan Manufaktur Yang Terdaftar Di Bursa. Efek Indonesia. Skripsi.Universitas Sumatera Utara.

Silalahi, Ulber. 2009. Metode Penelitian Sosial. Bandung; PT. Refika Aditama.

Sugiyono. (2010). Metode Penelitian Kuantitatif, Kualitatif, dan R\&D. Bandung: Alfabeta.

Sugiyono. (2012). Metode Penelitian Bisnis. Bandung: Alfabeta.

Suharsimi Arikunto. (2010). Prosedur Penelitian Suatu Pendekatan Praktek. Jakarta : Rineka Cipta.

TantrianiSukmaningrum. (2012). Analisis Faktor-Faktor Yang Mempengaruhi Kualitas Informasi Laporan Keuangan Pemerintah Daerah (Studi Empiris Pada Pemerintah Kabupaten Dan Kota Semarang). Skripsi. Semarang: Universitas Diponegoro.

Teni, Jenahas (2014, 19 Maret). Pemda Matim Bantah Gunakan APBD Manipulasi. tribunnews.com [Online]. Tersedia: http://kupang.tribunnews.com/2014/03/19/pemda-matim-bantah-gunakanapbd-manipulasi. [09 April 2014]

Uma Sekaran. (2007). Research Methods For Business. Jakarta: Salemba Empat.

Villadsen, A. R. (2011). "Structural Embeddedness of Political Top Executives asExplanation of Policy Isomorphism". Journal of Public Administration Research and Theory.

Wahyu Setiawan. (2012). Pengaruh Akuntabilitas Laporan Keuangan Pemerintah Daerah (LKPD)Terhadap Tingkat KorupsiPemerintah Daerah Di Indonesia. Skripsi. Semarang: Universitas Diponegoro.

$\mathrm{Xu}$, et al. (2003). "Key Issue Of Accounting Information Quality Management : Australian Case Studies". Industrial Management \& Data System 103/7, 461- 470.

Yayat Hayati Djatmiko. (2002). Perilaku Organisasi. Bandung: Alfabeta. 